\title{
Contextualizing the Development of Ukrainian Higher Education: Between Soviet Legacies and European Regionalization
}

\author{
Nataliia Zakharchuk \\ University of Saskatchewan
}

\begin{abstract}
This paper contextualizes the development of Ukrainian higher education in broad historical, geopolitical, and socio-economic realities. The author argues that these realities determine the current Ukrainian education trajectory. Higher education reforms in Ukraine are analyzed in the context of two major influences: European regionalization and inherited Soviet structures in education. Particular focus is placed on the Bologna Process, the European education initiative to standardize higher education in Europe. Soviet organizational and administrative principles are outlined and analyzed as the second influence that determines Ukraine's unique educational developments.

A brief overview of higher education reforms in Ukraine notes the distinctive changes in the legal framework between 1996 and 2014. Ukrainian education reforms within this period are viewed from the perspective of the Bologna Process, a series of voluntarily agreements between European countries to establish a common European Higher Education Area to retain the regions' influence and competitiveness. Contesting voices regarding the European-associated education reforms range from unquestionable support (Europhiliac) to absolute rejection (Europhobic). Such contesting voices reflect the Ukrainian society's broader understanding of its complex educational challenges. The author argues that public concerns about reforms in Ukraine initiated with the Bologna Process, originate in the nature of the reforms, the Ukrainian educational system and its foundational principles, public stereotyping of the reforms, and the unstable political situation in the country.
\end{abstract}

Keywords: European regionalization, the Bologna Process, Ukrainian higher education, Soviet education legacies.

\footnotetext{
$\mathbf{G}$ lobal competitiveness pressured higher education actors who share a designated area to form reginal alliances. The late twentieth century has seen the emergence of regionalization initiatives, such as the European common education area (Knight 106). European regionalization triggered significant changes in Ukrainian higher education. Ukrainian educational reforms have become of particular interest as specific historical, geopolitical, and socio-economic realities continue to determine Ukraine's educational trajectory. To compete internationally, Ukraine has to transform its
} 
inherited centralized Soviet system of education and become more marketoriented (Zeludenko and Sabitowa 852, 865; Sikorskaya 10). With this goal, in 2005 Ukraine joined the Bologna Process, a series of voluntarily agreements between European countries to establish the European Higher Education Area (EHEA) and to ensure academic mobility and quality of higher education in the region (European Higher Education Area, The Bologna Declaration). Since then, the country has become a part of the EHEA and has participated in "the creation of a knowledgeable and competitive European community" (Kushnir 11). This commitment has led to broader and more substantial educational reforms within the scope of the new proEuropean national policies. The new educational direction has been reflected in national strategies, government policies, and institutional practices, and, as such, is heatedly debated by government officials, educational theorists, and education practitioners. ${ }^{1}$

Much of the current literature discussing European regionalization provides a nation-specific analysis of the regionalization initiatives. The studies tend either to present the transformation experiences of each particular country within the EHEA ${ }^{2}$ or to compare and contrast the Europeanization efforts between countries, highlighting similar trends and identifying unique trajectories. ${ }^{3}$ Particular attention has been paid to the influences of European initiatives on the development of education systems in post-Soviet countries. ${ }^{4}$ Such educational reforms face difficulties due to persistent obsolete ideas prevailing in the societies as remnants of Soviet ideologies. Many studies have been conducted on how the specifics of Ukrainian education respond to Europeanization. ${ }^{5}$ However, only limited attempts have been made to present a holistic picture of Ukrainian higher education developments within specific socio-political realities (Oleksiyenko).

This literature review article focuses on the education reforms undertaken by Ukraine since joining the EHEA and provides a broader national context to understand these reforms and to shed light on emergent educational directions. I begin by briefly reviewing the context of higher education in Ukraine before the country's formal affiliation with the EHEA. I outline the European regionalization and explain how it has reshaped the global (including the Ukrainian) educational landscape. The Ukrainian national context and the specific historical, geopolitical, and socio-economic

\footnotetext{
${ }^{1}$ See Kvit; Nikolaiev, "Foreword"; Sovsun; Wynnyckyi 66-68.

2 See Dobbins; Sabzalieva.

${ }^{3}$ See Dangerfield; Dobbins and Khachatryan; Luchinskaya and Ovchynnikova.

${ }^{4}$ See Luchinskaya and Ovchynnikova 24-30; Yahorau and Antashkevich 2-18.

${ }^{5}$ See Gomilko et al.; Shaw; Shaw et al.; Yahorau and Antashkevich 15-18.
} 
factors affecting the Ukrainian education trajectory are explored next. Particular attention is paid to contesting voices in the literature on the European-associated education reforms.

\section{EUROPEAN REGIONALIZATION AND THE BOLOGNA PROCESS}

Regionalization has become a significant external influence on higher education worldwide and is often viewed as "a notable evolution" of internationalization (Knight 105). New strategic connections and relationships evolve between higher education systems, structures, and actors (Knight 106). These processes challenge existing power dynamics among leading nation-states and re-map the higher education landscape (Knight 106-107; Zmas 727-29). The aim of educational regionalization is to retain a region's weight in world affairs and to make its higher education more attractive and competitive (Zmas 729). Such reconfiguration of educational structures have introduced emerging regions in Africa, Asia, Europe, and Latin America to new education policies and initiatives, and have added new players to the educational arena, such as the African Union, the Association of South East Asia Nations University Network, as well as the EHEA (Knight 106-107).

In the estimation of scholars, European regionalization is the most influential regional initiative so far (Austin and Jones 190; Knight 106; Neave and Maassen 138). Such a claim is supported by the following arguments. First, European regionalization poses significant challenges for national education systems both inside and outside the region. The states within the European region have to adapt their national policies and introduce significant reforms in their higher education to legitimize themselves within the area (Neave and Maassen 135). However, participating states discover new possibilities for intra- and inter-regional co-operation, as European regionalization creates the space for policy dialogue between EHEA countries as well as with prospective European partners (Zmas 728). Second, states outside the EHEA have to consider its emergence as a new and powerful competitor in the world of higher education. The EHEA is challenging the leading positions of countries like the USA, China, and Canada (Zmas 729). The EHEA becomes more attractive for international students from outside the region, as it promises wider prospects to study and work among the forty-eight participating countries. For instance, The European Higher Education Area in 2018: Bologna Process Implementation Report identified an important new trend: since 2011-12, the EHEA has experienced an increase from 2.27 to 3.59 in the weighted average share of international students from outside the EHEA (European Commission et al. 254). Third, Jane Knight recognizes Europeanization as "a catalyst and 
model" for similar regionalization efforts worldwide (109). Some European initiatives, such as the Bologna Process, have spread beyond the geographical borders of the region to Africa, Asia, and Latin America, and have become an example for other regions to follow (Knight 106-109).

Within the context of European regionalization, the Bologna Process is the most significant and "arguably the largest higher education regionalization project in the world" (Austin and Jones 190). It has already spread beyond Europe's geographical borders (European Higher Education Area [EHEA], The Yerevan Communique). The Bologna Process is an intergovernmental voluntary agreement to harmonize higher education across countries and to create a European community, competitive in a global knowledge-based economy (EHEA, The Bologna Declaration; Kushnir 11; Luchinskaya and Ovchynnikova 21). To achieve these purposes, participating countries must introduce a number of reforms to their national education systems.

Although the Bologna Process formally started with the 1999 Bologna Declaration, it was initiated long before by the signing of the Magna Charta Universitatum, which prescribed the fundamental values of the university in 1988 (Neave and Maassen 135). As a voluntary agreement, the Bologna Process began with only four countries-Britain, France, Germany, and Italy (EHEA, The Sorbonne Declaration) - and evolved into a large global initiative supported by forty-eight participating countries (EHEA, The Yerevan Communique). The Bologna Process evolved gradually through a range of meetings in Prague (2001), Berlin (2003), Bergen (2005), London (2007), Leuven (2009), Budapest-Vienna (2010), Bucharest (2012), Yerevan (2015), and Paris (2018), each followed by an affirmed range of actions toward the establishment of the EHEA. The action lines were subsequently "translated" into corresponding higher education reforms at the national level.

As the targeted areas of the Bologna Process reforms were students and teachers' mobility, systems of easily comparable degrees and transferable credits, co-operation in quality assurance, and life-long learning (EHEA, Towards the European Higher Education Area), the national level reforms were meant to standardize some key higher education elements among the participating countries (Stensaker et al. 2). Correspondingly, systems of compatible degrees, transferable credits, and equal academic qualifications within the European states and some non-European member countries were developed and implemented (EHEA, Making the Most of Our Potential). The national reforms alongside the action lines were based on the fundamental principles of the Bologna Process: autonomous universities, the participation of students in higher education administration, public responsibility for higher education, and the social dimension of the Bologna Process (EHEA, The Bologna Declaration). Therefore, while the Bologna principles laid the foundation for the development of European higher 
education, a harmonization of the entire academic system of the region was intended through the key reform areas.

In the case of Ukraine, the Bologna Process triggered not only profound national reforms in education, but also initiated heated debates on the changes, related to the Bologna Process; their educational and cultural expediency; and Ukraine's political and social readiness to follow the European direction. The continuum between Europhilic and Europhobic orientations is used to follow the debates and to analyze the shift in contesting voices regarding higher education reforms in Ukraine between 1996 and 2014.

\section{FRAMEWORK OF ANALYSIS}

Over the years, political views of the European Union and so-called Europeanization have changed many times in European states, from unquestionable support to complete rejection. The concept of Euroscepticism was first introduced in the British political sphere to describe opposition to European integration (Ultan and Ornek 52). Later, this concept was used in the analysis of political views in central and eastern Europe. For example, Petr Kopecky and Cas Mudde critique the notion of Euroscepticism and suggest a more comprehensive conceptualization of existing political party positions. They locate party positions in east central Europe in relation to two dimensions - support of or opposition to the ideas of European integration (Europhiles vs. Europhobes) and support of or opposition to a European Union (EU) (EU-optimists vs. EU-pessimists) (302303). Analyzing the case of Serbia and Croatia, Marko Stojic noted that Kopecky and Mudde's framework did not reflect the party positions in the states that did not question either European integration or the establishment of the EU; rather, they questioned the positions of the countries in the process of becoming EU member states (314). Therefore, Stojic's conceptualization of political orientations toward EU membership represents a continuum from Europhile to Europhobe: Euroenthusiasts (strong support), Europragmatists (support with some limitations), Eurosceptics (not positioned or rejection under current conditions), and Eurorejects (strong general rejection) (317). The conceptualization of the continuum rejects the static nature of political views and their binary opposition and adds a dynamic to the analysis of political orientations toward EU membership. Although useful in politics, the four positionsEuroenthusiasts, Europragmatists, Eurosceptics, and Eurorejects-are hard to apply in an educational context, as conditional support and conditional rejection are often too close on the continuum to differentiate. 
Such political conceptualizations have been borrowed and reinterpreted within the education sphere. Similarly, Guy Neave posits three approaches to European higher education policy: Europhiliacs, who are full of hope and optimism about European educational initiatives, Europhobics, who are extremely pessimistic, and Eurosceptics, who are not in opposition to European education initiatives but tend to look for obstacles to successful education policies. In Neave's opinion, Europhobics' pessimism keeps them from moving at all: they "dwell ... in the past, know ... the cost of everything and value of nothing," whereas the pragmatism of Eurosceptics allows them to exercise agency guided by the strategy and tactics necessary for policy making and "the provision of 'grounded intelligence'" $(113,114)$. Considering that the political concept of Eurosceptic means "in opposition to European integration," the use of this term by Neave with respect to European higher education policy might cause confusion.

To navigate among the contesting voices in Ukrainian scholarship on European regionalization and the Bologna Process in Ukrainian higher education, I propose to combine the conceptualizations suggested by Stoijic and Neave and visualize the lens of support and opposition as a continuum between Europhilia and Europhobia. However, instead of Euroscepticism, I adopt the term "Eurorealism" as a tentative "in-between" concept. Eurorealists take a moderate stance in their support of the pro-European education policy. Guided by evidence and logic, they are careful in evaluating their country's current education position and Europe-associated reforms. By using the continuum between Europhilia and Europhobia, I have no intention to simply place Ukrainian scholars between the two extremes or create a negative attitude towards either or both directions. Instead, this lens allows me to track the contesting arguments in the recent Ukrainian scholarship on higher education reforms.

Contesting arguments in the debates on Europeanization in politics and education are usually grounded in a country-specific context and consider social and historical factors that underlie a country's support for or opposition to European integration or the EHEA. Ukraine's historical, geopolitical, and socio-cultural contexts have always determined the country's integration choices and the attitudes of Ukrainians toward Europeanization.

\section{UKRAINIAN CONTEXT}

\section{Historical and Geopolitical Perspective}

Ukraine became an independent European country in 1991, after the collapse of the Soviet Union, but Ukrainian statehood and identity began to 
form much earlier, during the ninth century, when Kyivan Rus' emerged as the first eastern Slavic state. Kyivan Rus' was one of the largest and most powerful states in Europe until the thirteenth century (Kubicek 17-20; Morelli 1; Subtelny 34-37). Conquered, divided, and ruled by various powers, Ukraine had only a short period of independence-after the collapse of czarist Russia in 1917 (Kubicek xiv-xv, 108-109; Subtelny 355-70). From 1922 to 1991, Ukraine was a part of the Soviet Union and governed by the Communist Party. This era in Ukrainian history was marked by a Soviet ideology, a collective rather than a national identity, and a planned rather than a market economy (Dragneva and Wolczuk 11; Niyozov 92). Ukraine experienced a man-made famine in 1932-33 (a genocide of the Ukrainian people, also known as the Holodomor), political repressions, and a continuous struggle for national self-determination (Applebaum 211-21; Subtelny 403-90). This era came to an end when Ukraine gained its independence from the Soviet Union and was officially recognized as a sovereign state.

Located in central and eastern Europe between Europe and Asia, Ukraine occupies a "sensitive position between Russia and North Atlantic Treaty Organization (NATO) member states Poland, Slovakia, Hungary, and Romania" (Morelli 1). Ukraine is of great political importance to Russia, and therefore, it became caught in a protracted and tense relationship between Russia and NATO (Dragneva and Wolczuk 9; Johns 26; Kubicek 156-57). Ukraine's geopolitical situation caused political confrontations between proRussian and pro-European forces inside the country. Ukraine's movements back and forth between the association with the European Union and the "Russian-led integration regimes" have drawn global attention (Dragneva and Wolczuk 1). These political confrontations led to anti-government demonstrations and, consequently, to two revolutions: the Orange Revolution in 2004 and the Revolution of Dignity ten years later (Johns 2627; Kubicek 165; Morelli 2). As the nation has prioritized the Eurointegration policy, it has lost part of its territory and is caught in a war with Russia (Harasymiw; Johns 26-36; Morelli 21).

\section{Socio-Economic Perspective}

Apart from a sensitive geopolitical location, political unrest connected with "incessant bickering among rival political groups" (Kubicek 9), and an ongoing undeclared war with a neighbouring country (Harasymiw), Ukraine has experienced a number of socio-economic difficulties in the last 30 years. It has been a challenge for Ukraine to remain politically independent and to avoid reverting to "some Union-style entity" with Russia while managing its economic and energy dependencies on its neighbour (Dragneva and 
Wolczuk 9). Closely connected in industry and trade with the Soviet Union and internationally isolated from other countries for decades, Ukraine has struggled to move from a command planned economy to a market economy and to secure its economic stability (Dragneva and Wolczuk 13).

The move toward a new social order was another challenge for the Ukrainian nation. Similar to other former Soviet Union countries, Ukraine experienced certain paradigmatic shifts (Niyozov 92). In two such shifts Ukraine moved from being part of "the largest unified country with a single party and state monopoly" to an independent nation-state with multiple parties and various movements, and from being an atheistic state with a single ideology to a state with religious freedom and nationalist discourses (Niyozov 92). Therefore, the first years of independence were turbulent, considering the social problems involved in "creating an identity for a nation with territorial, ethnic, and linguistic issues" (Zeludenko and Sabitowa 865). Continuing challenges for the Ukrainian nation include the multiple reinterpretations of Soviet history offered by contending governments, be it the pro-independent Ukrainian government or neo-Soviet politicians (Oleksiyenko 134). However, a shift in the Ukrainian society from a passive to an active social role of individuals has been the most difficult, and Anatoly Oleksiyenko, in his study on higher education reforms in Ukrainian universities, argues that this shift has yet to be undertaken. Oleksiyenko concludes that the hierarchical system that still prevails in academia leads to a diminished belief in collegiality or individual agency, demotivation toward making institutional changes, and inertia in Ukrainian universities $(136,140-42)$.

Recent changes in ideology and social structure, coupled with a new political direction marked by an intention to step away from the Soviet model, have provoked Ukraine's education trajectory to shift in a European direction. To understand the extent to which this goal has been reached, the principles according to which the Ukrainian education system operated before the commitment to European standards are examined.

\section{UKRAINIAN HigHER EDUCATION BEFORE THE BOLOGNA PROCESS}

The distinctive features of Ukrainian higher education before the adoption of the Bologna Process were its inherited Soviet structures. Extremely centralized, complex, and multi-layered (Kremen and Nikolajenko 24-28; Zeludenko and Sabitowa 852-55, 863), Ukrainian higher education was mainly viewed as a legacy of the Soviet era (Dobko 76; Zeludenko and Sabitowa 852). Multiple attempts to rebuild and modernize it were always grounded in a discussion about historical and social parameters reflected in 
Soviet administrative principles and organizational structures (Kremen and Nikolajenko 11, 18; Osipian 234-35; Zeludenko and Sabitowa 852).

\section{Administrative Principles}

In their analysis of higher education in post-Soviet countries, scholars recognize elements of the extreme state-control and authoritarian governance as remnants of the Soviet era (Dobbins 20; Dobbins and Khachatryan 195-96; Dobko 77; Niyozov 92-102; Osipian 234-35). These elements can be traced back to the organizational principles present in the administrative core of Soviet education-uniformity, top-down administration, and one-person management (Kuraev 185-88). ${ }^{6}$ According to Alex Kuraev, uniformity was present in all vital academic issues. Central and peripheral institutions were structurally similar and followed the same basic rules; they provided training according to the same curriculum, and organized classes in the same way. Following a top-down administration principle, all decisions were made at the top and only executed at institutional levels-from the Ministry of Education through the territorial ministries without the participation of local and institutional-level administrators. Finally, undivided authority belonged to the chief administrator of an academic institution. Any order from a superior was expected "to be executed fully, exactly and within the given time frame" (Kuraev 188). These principles in Ukrainian higher education can still be observed, however, not at the same scale.

The three principles-uniformity, top-down administration, and oneperson management-have been manifested in the centralized and government-run nature of higher education in all post-Soviet countries. This means that Ukraine has a uniform national system of education that is centrally organized and is regulated by state laws and the decrees of the President of Ukraine and Ukraine's cabinet of ministers (Kremen and Nikolajenko 29-30; Zeludenko and Sabitowa 855). The state regulates higher education in Ukraine through the following legal framework: Konstytutsiia Ukrainy (Constitution of Ukraine), Zakon Ukrainy "Pro osvitu" (Law of Ukraine "On Education"), and Zakon Ukrainy "Pro vyshchu osvitu" (Law of Ukraine "On Higher Education"). Moreover, through the Ministry of Education and Science of Ukraine, the state supervises the majority of Ukrainian higher educational institutions (Verkhovna Rada Ukrainy, Zakon Ukrainy "Pro vyshchu osvitu," No. 1556-VII, 2014, Art. 12-13). Such supervision controls both national higher education policy and national quality assessment.

\footnotetext{
${ }^{6}$ See, also, International Qualifications Assessment Service (IQAS) 5.
} 


\section{Structural Legacies}

The complexity of Ukrainian higher education has always been the multilevel and multi-cycle degree system, ${ }^{7}$ which resembles degrees awarded under the Soviet system (Zeludenko and Sabitowa 863). In the Soviet Union, the three levels of incomplete, basic, and complete higher education were supplemented with interim scholastic awards. Even though university education consisted of two distinct phases that resulted in the Specialist Diploma (the first-degree program) and the Candidate of Sciences and Doctor of Sciences diplomas (graduate and advanced graduate programs), intermediate diplomas, such as Junior Specialist were also awarded (International Qualifications Assessment Service [IQAS] 6; Whiting 84). Each of these academic diplomas corresponded to specific professional qualifications. There was a so-called joint acquisition of educational and professional training (IQAS 6), with which students received academic and professional qualifications at the same time; that is, they mastered corresponding educational levels and simultaneously received professional training, and their diplomas were usually both educational certificates and professional licenses (Kremen and Nikolajenko 24). Concerns are expressed that such an inherited model of education often makes the distinction between university education and higher professional education unclear (Hladchenko et al. 115). Despite that critique, Ukraine still offers the three levels of incomplete, basic, and complete higher education and a combination of academic and professional certification (Kremen and Nikolajenko 24; Verkhovna Rada Ukrainy, Zakon Ukrainy "Pro vyshchu osvitu," No. 1556-VII, 2014, Art. 5).

The transition to the three-cycle degree system of bachelor, master, and doctor recognized by the rest of the world has been long and challenging. Regardless of the corresponding adjustments gradually introduced by 2002 and 2014 versions of the Law of Ukraine "On Higher Education," degrees of Junior Specialist and Specialist have been granted by some institutions in addition to junior bachelor, bachelor, and master degrees (Gomilko et al. 185; Zeludenko and Sabitowa 863). Moreover, graduate and advanced graduate degrees of Candidate of Sciences and Doctor of Sciences collided with the Doctor of Philosophy, merging into the Doctor of Philosophy and Doctor of Science degrees (Kremen and Nikolajenko 25; Verkhovna Rada Ukrainy, Zakon Ukrainy "Pro vyshchu osvitu," No. 1556-VII, 2014, Art. 5). The resultant clash between Soviet university tradition and European-level education reforms, according to Taras Dobko (77), Olga Gomilko and others

\footnotetext{
7 See both versions of the Law of Ukraine "On Higher Education" (2002, Art. 6, and 2014, Art. 5).
} 
(178), and Anatoly Oleksiyenko (134), caused the hybridization of Ukrainian higher education.

To add to this complexity, Ukraine has preserved (with minor adjustments) the Soviet differentiation of degree-granting establishments. Universities, institutes, higher technical colleges, military schools, and various other institutions that existed in the Soviet Union (IQAS 6; Whiting 82) have survived in Ukraine after major educational reforms (Verkhovna Rada Ukrainy, Zakon Ukrainy "Pro vyshchu osvitu," No. 1556-VII, 2014, Art. 29). Thus, the Ukrainian higher education network consists of over six hundred educational institutions that possess various accreditation levels (Derzhavna sluzhba statystyky Ukrainy). They progress from Levels I and II-non-university vocational and technical establishments, respectivelyto Level IV institutions - universities, conservatories, academies, and some institutes that conduct independent research and can award doctorates (Zeludenko and Sabitowa 862-63; Verkhovna Rada Ukrainy, Zakon Ukrainy "Pro vyshchu osvitu," No. 1556-VII, 2014, Art. 29). The state determines whether an institution with these levels has a right to exercise relevant educational activities and to assure that the education provided is sufficient to qualify the recipient for a doctoral degree (Verkhovna Rada, Zakon Ukrainy “Pro vyshchu osvitu," No. 1556-VII, 2014, Art. 29).

The centralized character of Ukrainian education and its structural complexity testify to the survival of Soviet administrative and organizational principles. Although education in Ukraine bears these remnants, a shift in the value systems is reflected in the new pro-European priorities, in the reconstruction of educational aims, and in the further development of Ukrainian higher education. These transformations are aligned with European education policies.

\section{Following The Bologna PROCESS PATH}

Since its political independence, Ukraine has been restructuring its initial post-Soviet education plan under the influence of nationalist movements from inside the country and globalizing influences from outside. As a postSoviet country, Ukraine is moving from a communist society to a postcommunist society with distinct national motives in policy and education (Dobko 78; Scott 277-78). The country is still rediscovering its national identity and introducing new national values into education (Dobko 78; Myshchyshyn 5; Sikorskaya 11). As a European country, Ukraine's international direction has been greatly predetermined by its geographical location. The key motives of security, national identity, and modernization drove Ukraine toward European integration (Dragneva and Wolczuk 30), and accordingly, "to follow the path it started on in the 1990s toward 
decentralization and opening the land up to Europe" (Zeludenko and Sabitowa 865). Although Ukraine started its integration into the EHEA and joined the Bologna Process in 2005, the implementation of European principles in Ukrainian higher education began earlier.

\section{National Legislation within the Bologna Process Framework}

The development of Ukrainian higher education in the context of the Bologna Process is a gradual process involving the introduction of new ideas and approaches. Europeanization has brought changes into the three major areas of Ukrainian education: the system of higher education, the system of quality assurance, and the relations between the Ukrainian state and the university (Kostrobiy and Rashkevych 17-19; Wynnyckyi 67-70). As a result, a number of steps at the Ukrainian national level have been taken to adjust the legal framework-from the Law of Ukraine "On Higher Education" and the Presidential Decree "Pro Natsional'nu doktrynu rozvytku osvity" ("On the National Doctrine to Develop Education"), both of 2002, to the Law of Ukraine "On Higher Education" of 2014 (Verkhovna Rada Ukrainy). The legal framework now clearly conveys the idea that the Ukrainian state encourages the integration of its national education into the European and global community. Therefore, the national integration into the European education community can be vividly traced by comparing the Bologna principles with the corresponding developments in Ukrainian legislation.

The changes in the system of Ukrainian higher education concerned the introduction of distinctive degrees, a three-degree system, and the introduction of transferable credits. When these action lines were asserted in the Bologna Declaration in 1999 (EHEA), Ukraine responded quickly, taking a number of actions before its formal commitment to the Bologna Process initiative. Thus, following the Lisbon Recognition Convention of 1997, Ukraine introduced adjustments to higher education qualifications (the degrees and the periods of study) through the Zakon Ukrainy "Pro ratyfikatsiiu Konventsii pro vyznannia kvalifikatsii $z$ vyshchoi osvity $v$ Ievropeis'komu rehioni" (Law of Ukraine "On the Ratification of the Convention on the Recognition of Higher Education Qualifications in the European Education Area"), and the Law of Ukraine "On Higher Education," with a series of ministerial orders and decrees (Stepko et al. 27-32). Subsequent changes regarding the introduction of a credit-module system and the implementation of the European Diploma Supplement occurred gradually 
from 2004 to 2010. Legally, these changes were regulated by the Ministry of Education and Science of Ukraine through various acts, decrees, and letters. ${ }^{8}$

The introduction of the three-cycle degree system was the longest and the most challenging structural transformation. The process started as early as 1996 with the Law of Ukraine "On Education," and the educational levels of bachelor's and master's degrees were regarded in more detail six years later in the Law of Ukraine "On Higher Education." However, some scholars argue that real transformation had not been accomplished even in 2014 with the newest version of the Law of Ukraine "On Higher Education" (Gomilko et al. 185). Olga Gomilko and others posit that instead of the three-degree system, there is still a hybrid six-degree system (junior bachelor, bachelor, specialist, master, Candidate of Sciences, and Doctor of Sciences), which carries remnants of the Soviet past (186).

The system of quality assurance was the second area that had to undergo transformations, according to the Bologna Declaration (EHEA). To align Ukrainian higher education with European requirements, Ukrainian legislation was introduced to transform the quality assurance system. According to the Law of Ukraine "On Higher Education" of 2002, higher educational institutions, the state, and the public co-operated to ensure external and internal quality control (Verkhovna Rada of Ukraine, No. 2984III, Art. 28). The external assessment was carried out through the licensing and accreditation of degree programs and of higher education institutions, through attestations of students and state inspections (Art. 28). ${ }^{9}$ These responsibilities belonged to the Ministry of Education and Science of Ukraine, the State Accreditation Commission, and the State Inspectorate. Since quality assurance strategies were enacted, quality assurance has continued to progress toward greater transparency. As reflected in the laws of Ukraine, Ukraine is establishing a separate governmental unit called the National Quality Assurance Agency. Moreover, Ukrainian higher education institutions are obligated to develop internal policies for quality assurance.

\footnotetext{
${ }^{8}$ Some examples of the laws issued by the Ministry of Education and Science of Ukraine are "Pro vprovadzhennia kredytno-modul'noi systemy orhanizatsii navchal'noho protsesu" ("On the Introduction of Credit-Modular System As a Principle of Organization of Educational Process"), "Pro zaprovadzhennia dodatka do dyploma Ievropeis'koho zrazka" ("On the Introduction of the European Diploma Supplement") (Ministerstvo osvity i nauky Ukrainy), and "Pro zatverdzhennia planu dii shchodo zabezpechennia iakosti vyshchoi osvity Ukrainy i ii intehratsii u ievropeis'ke i svitove osvitnie spivtovarystvo na period do 2010 roku" ("On the Approval to Implement the Action Plan to Ensure the Quality of Higher Education in Ukraine and Its Integration in the European and World Education Community for the Period until 2010”) (Verkhovna Rada Ukrainy).
}

${ }^{9}$ See, also, Stepko et al. 24. 
However, Ukraine is still among the countries that allow their institutions to decide whether to make enacted policies public (European Commission 129).

The last area of required changes-reforms in a state-university relationship -is heatedly debated in Ukrainian scholarship (Dobko 81; Nikolaiev, "What Has Been Achieved" 21-22; Osipian 235; Sovsun 6-7; Wynnyckyi 70). Decentralization, autonomy, and university self-governance as foundational Bologna Process ideals were gradually implemented in Ukrainian education through the 2002 and the 2014 versions of the Law of Ukraine "On Higher Education." Due to pressure from the EHEA, the historically inherited centralized management of Ukrainian education was forced to change, and Ukrainian universities were legally granted autonomy from the state (Verkhovna Rada Ukrainy, Zakon Ukrainy "Pro vyshchu osvitu," No. 1556-VII, 2014, Art. 32). However, Ukrainian scholars and policy-makers share the opinion that it is premature to talk about university autonomy when universities still depend entirely on the state for financing and budgeting (Dobko 81; Kvit; Nikolaiev, "What Has Been Achieved" 21-22; Osipian 236; Sovsun 6-7).

In the years between 1996 and 2014, Ukraine's way to the EHEA was cleared because the fundamental Bologna Process principles had been introduced and enacted in Ukraine through major legislation. In particular, 2014 became a watershed for Ukrainian education, as a new version of the Law of Ukraine "On Higher Education" was issued and proved to be a turning point in the country's efforts to provide the quality of education and to obtain international recognition (Shandruk and Shatrova 135; Sovsun 4).

\section{A Step Forward or a Failure in Ukrainian Legislation}

The 2014 Law of Ukraine "On Higher Education" was the most significant milestone toward the Europeanization of Ukrainian Education. Often referred to as a guide to necessary education changes (Nikolaiev, "Foreword") and the first major reform in the improvement of higher education (Sovsun 4), the Law of Ukraine "On Higher Education" has received contradictory evaluations from the public. On one hand, the public considers this law to be a progressive state policy (Kvit) because it is a joint effort by the government, leading universities, and the public, and conveys the values and interests of all stakeholders in higher education (Nikolaiev, "Foreword"; Sovsun 4). The Law of Ukraine "On Higher Education" introduces the main Bologna Process principles into the state policy: life-long education, 
accessibility to higher education, and Ukraine's integration into the EHEA. ${ }^{10}$ Moreover, to ensure the quality and transparency of higher education, a new quality assurance system has been developed, and the state-university relationships are reviewed, emphasizing universities' academic and financial autonomy. ${ }^{11}$ On the other hand, Olga Gomilko and others emphasize that there are severe inconsistencies in the Law of Ukraine "On Higher Education," as two teams with conflicting interests-pro-Russian and pro-European-have been working on this legislation (185). These efforts have not changed the situation in Ukrainian higher education dramatically (Gomilko et al. 185; Sovsun 4), and Ukrainian higher education still holds remnants of "the modified old and cumbersome system" (Gomilko et al. 186).

However, among the opposing views on the Law of Ukraine "On Higher Education," there is a shared opinion that this law provides a solid basis for transformations of higher education and sets forward the guidelines for the development of the education system (Kvit; Nikolaiev, "Foreword"; Sovsun 4-10). Even though further institutional reforms are much needed (Kostrobiy and Rashkevych 19; Nikolaiev "What Has Been Achieved" 27; Sovsun 4), the legal framework reflects the Ukrainian society's broader understanding of the complex problems in education (Sovsun 13) and points the way toward European educational regionalization. Despite the evident support for Europeanization in national politics, it is presumptuous to describe Ukrainian attitudes about education as moving exclusively toward the Europhilic side of the continuum. A more analytical and critical assessment of existing Ukrainian scholarship is needed to conclude on its prevailing direction between Europhilia and Europhobia.

\section{BETWEEN EUROPHILIA AND EUROPHOBIA}

\section{Contesting Voices on European Regionalization}

Since independence, Ukraine's international co-operation and cross-border collaboration continued to grow exponentially. The scope of Ukraine's international relationships has widened from the former Soviet Union countries to numerous partners in all parts of the world (Kremen and Nikolajenko 58). The active international education policy reflects the country's striving to stay competitive in the global market, to reduce the

\footnotetext{
10 See Verkhovna Rada Ukrainy, Zakon Ukrainy "Pro vyshchu osvitu," No. 1556-VII, Art. 3.

11 Verkhovna Rada Ukrainy, Zakon Ukrainy "Pro vyshchu osvitu," No. 1556-VII, Art. 17-21, 32.
} 
outflow of Ukrainian students, and to attract international students (Stratehichna doradcha hrupa "Osvita" 3-4). Although Ukraine's internationalization strategy is not limited to EHEA members, Ukraine pursues a predominantly pro-European policy in higher education (Kushnarenko and Knutson 26; Verkhovna Rada Ukrainy, Zakon Ukrainy "Pro vyshchu osvitu," No. 1556-VII, 2014, Art. 74).

Opposing opinions on Ukraine's evidently pro-European education policy have accompanied the major educational reforms from the beginning. More enthusiastic Europhilic attitudes can be traced to the early stages of higher education transformations. During the first decade of implementing the Bologna Process reforms, many scholarly works supported Ukraine's prime focus on European regionalization. Their support reflected Ukraine's efforts to modernize higher education and improve its quality, as well as to open the system to international influences and to become a part of the European knowledge society (Bosenko 686; Dubaseniuk 135-36; Hurch 23; Ponomar'ov and Shpatenko 65). Modernization was primary viewed as education fundamentalization, humanization, and differentiation, considering the emergence and distribution of modern technologies (Bosenko 685-86; Dubaseniuk 135-36). Other drivers of Euroenthusiasm were the prospects of recognition of Ukrainian academic degrees abroad, the higher mobility and employability of Ukrainian graduates, external funding for education, and the attraction of international partners to Ukrainian research (Bosenko 686; Hurch 28-32; Kostrobiy and Rashkevych 14; Kushnarenko and Knutson 26-27).

Over time, the public response in favour of the Bologna Process has taken a more moderate stance, and includes some critical perceptions of the reforms (Gladushyna 107-11; Gomilko et al. 177; Oleksiyenko 133-37; Sikorskaya 10). The main public concerns are related to the nature of the reforms, the foundational principles of the Ukrainian educational system, negative public stereotyping of Bologna Process-initiated reforms, and the unstable political situation in Ukraine. These concerns are elaborated below.

\section{The Nature of Ukrainian Higher Education Reforms}

Prior to the reformation of higher education in Ukraine, some scholars were cautious about the nature of the reforms associated with the Bologna Process. The issue of mindless standardization instead of meaningful transformation was debated in both European and Ukrainian literature (Ponomar'ov and Shpatenko 69; Stensaker et al. 2; Unynets'-Khodakivs'ka and Matseliukh 35). Supporting a general pro-European direction of the education reforms, Ponomar'ov and Shpatenko warned against adopting a narrow focus of transformations limited only to the Bologna Process 
framework and applying standardization to some educational elements. They emphasized that a mechanical transfer of foreign experience and a formal uniformity of norms and principles would not substitute for a deep and meaningful modernization (Ponomar'ov and Shpatenko 69).

In her analytical and rather critical stance on the Europe-associated reforms, Inna Sovsun noted that a lack of a coherent national development strategy could prevent a meaningful modernization of higher education in Ukraine (5). She stated that neither the Ukrainian society nor the Ukrainian universities fully comprehended the role of higher education in the development of the country (Sovsun 5). Several critics observed that there was no clear and coherent vision of the development of the national education system and separate institutions, no national consensus on the Bologna Process reforms, and, most importantly, no unanimous conviction that the reforms were necessary (Kvit; Semenets' 108; Shandruk and Shatrova 135; Sikorskaya 11; Sovsun 5). Many questioned whether quality modernization had taken place in Ukraine's move toward Bologna Process reforms (Dobko 86; Gomilko et al. 184; Oleksiyenko 142-46; Shandruk and Shatrova 136). For instance, Gomilko and others estimated the transformations in Ukrainian education to be of a "cosmetic nature instead of a substantial one" (184). Svitlana Shandruk and Zhanna Shatrova observed that the major structural reorganizations of Ukrainian institutions lacked coherence, citing the six-degree system and the state-university relationship as examples (136-37).

\section{The Foundational Principles of the Ukrainian Educational System}

The concerns about the Ukrainian educational system and its foundational principles strengthen the shift from a primary Europhilic towards a more Europhobic direction. Since Ukrainian education can still be described as "transitioning" from its Soviet legacies, there are certain mismatches between Ukrainian educational philosophy formed during the Soviet era and so-called Western views on education (Dobko 77; Hurch 23; Shaw 17, 19). Some go further and state that the Ukrainian system is simply incompatible with the European system (Gomilko et al. 182-86; Kuznietsova 58). Gomilko and others argue that the rigidity of the Ukrainian education system and the unwillingness to abandon the previous Soviet norms and structures have led to "unproductive hybridity" in the current Ukrainian-European education system-the hybridity being a combination of viable "versions of crossbreeding postcolonial, post-totalitarian, liberal-democratic and national educational trends" $(185 ; 195)$. According to these scholars, 
[t] he combination of cultural phenomena of our time, which go beyond it, [and] has important implications for HE [higher education]. On the one hand, the involvement into the Bologna process is an example of presentday European standards. On the other hand, the dominance of non-modern and pre-modern educational elements (colonial, Soviet, national) are deeply rooted in Ukrainian education. Thus, liberal democratic Bologna models transform themselves into unattractive "mutants," which are not typical for either progressive global strategy, not even for traditional local education practices. (Gomilko et al. 185)

Such crossbreeding, according to Oleksiyenko, has created the neo-Soviet system, "a much worse replica of the Soviet model" (136). This neo-Soviet system has been reflected in the strengthened post-Soviet bureaucracy and peripheral vision of the role of education (Oleksiyenko 136). It has resulted in low wages, poor working conditions, outdated equipment at the universities, a lack of professional motivation, extreme corruption, and a significant loss of moral values.

\section{Public Stereotyping of the Bologna Process-initiated Reforms}

Ukraine's society has provided only conditional support for European initiatives in Ukrainian education. As a nation deprived of a national idea for a century, efforts to introduce the national component in education as well as to develop education under European principles are critical for Ukrainians. (Kremen and Nikolajenko 18; Khrestin 49-56; Zeludenko and Sabitowa 852). The introduction of national values in higher education has been occurring gradually over several decades, with constant public debates on the status of the Ukrainian language and with the rediscovery of the Ukrainian identity (Khrestin 54-56). The turning point occurred in 2002 with the publication of the Presidential Decree "On the National Doctrine to Develop Education," which contains the legal framework to affirm a national idea and promote a national self-identification. A revival of national values was not easy, and concerns were expressed about a possible loss of national identity if Ukraine pursued integration in the EHEA (Myshchyshyn). The public fear that internationalization might interfere with the preservation of the national component in education was accompanied by a fear of again losing sovereignty in decision making (Hurch 23). Hurch attributed such public stereotypes to the long-term absence of regular interactions between Ukraine and European countries (23). Such fears have hindered the implementation of Bologna Process-initiated reforms in Ukrainian higher education. 


\section{Ukraine's Unstable Political Situation}

Concerns about the inability of the Bologna Process reforms to work in contemporary Ukraine also arise from the unstable political situation. The military conflict with Russia that began after the 2013-14 Revolution of Dignity and the later Russian annexation of Crimea hinder the operation of universities and challenge the education system in general (Oleksiyenko 134; Osipian 239; Peterson; Popa). For example, Olesya Gladushyna and Isabella Popa reported that Ukrainian university students and personnel were evacuated from the occupied areas of Donetsk Oblast, Luhansk Oblast, and the Crimean Peninsula due to military activities (Gladushyna 109). The universities lost campuses, equipment, and records, and students were forced to look for other places to continue their education. Many students put their education on hold and volunteered to join the military forces fighting in the conflict regions (Peterson).

Existing voices critical of the Bologna Process reforms cannot be characterized as Europhobic or pessimistic, but rather as Eurorealistic. They acknowledge existing Ukrainian realities, both social and educational, and identify necessary steps to make the Bologna Process reforms work in these realities. For example, in her assessment of Ukrainian reforms, Sovsun recognizes that they will not bring immediate changes, and the results will be more evident in the long run (13). The task was initially set so broad that one-time results cannot be expected; instead, everyone should be prepared for a marathon, not a short distance run (Sovsun 13). Acknowledging the absence of dramatic changes in educational practice, scholars continue to look for productive strategies to move toward Europeanization. Viktoriia Kuznietsova suggests that Ukraine should solve internal economic, social, and political issues before adopting the Bologna Process (58-59). One goal might be to reconsider the established relationships between academia, the state, and the market.

Scholars suggest that apart from solving internal national problems, the country should concentrate more on the institutional rather than the national dimension of the reforms (Kovtun and Stick 91; Kushnarenko and Knutson 26; Shpatenko 72). According to S. A. Shpatenko, a vital issue on the agenda should be to form a new philosophy of education that would transform the requirements of a transitioning society into specific tasks for institutions (72). Likewise, a former Ukrainian Minister of Education Serhii Kvit promotes an institutional focus in the discussion of Ukraine's reorganization of education. He attributes the inconsistencies between the national reforms and their implementation at the institutional level to two factors. First, there are few administrators who are competent to implement the educational changes. Second, the majority of reforms are undertaken by 
state figures brought up on Soviet ideologies, leaving the success of the reforms in question (Kvit).

\section{CONCLUSION}

Ukrainian higher education is a product of historical and socio-political conditions. It is influenced by inherited Soviet structures and by European regionalization, particularly the Bologna Process. The core policy areas of the Bologna Process have reshaped the national policy in Ukraine and have entailed profound reforms. Every step that Ukraine has made toward European higher education needs to be seen in a broader Ukrainian national context, which can explain the deflections to some extent from the European direction.

Ukraine's active pro-European policy and the country's striving to stay competitive in the global education market has raised public debates about the success of such internationalization strategy. Over the last two decades, different perspectives on the matter have ranged from optimistic and extremely Europhilic to openly Europhobic. However, neither the challenges evoked by integration with the EHEA nor the resistance stemming from deeply rooted Soviet principles hinders the predominant Eurorealistic tendencies in Ukrainian society. While the problems and inconsistencies in educational reforms are acknowledged, scholars and government figures are encouraged to exercise agency and think strategically about the future steps that must be taken to reform Ukrainian higher education. 


\section{Works Cited}

Applebaum, Anne. Red Famine: Stalin's War on Ukraine. Doubleday \& Co., 2017.

Austin, Ian, and Glen A. Jones. Governance of Higher Education: Global Perspectives, Theories, and Practices. Routledge, 2016.

Bosenko, Maryna. "Issues Related to University Education in Ukraine in the Context of Globalization, European Integration and Bologna Process." European Researcher, vol. 72, no. 4-1, 2014, pp. 683-88, http://www.erjournal.ru/journals_n/1398793364.pdf. Accessed 9 July 2020.

Dangerfield, Martin. "Belarus, Moldova, and Ukraine: In or Out of European Regional International Society?" Journal of European Integration, vol. 33, no. 2, 2011, pp. 215-33. DOI: 10.1080/07036337.2011.543527.

Derzhavna sluzhba statystyky Ukrainy. "Zaklady vyshchoi osvity." Derzhavna sluzhba statystyky Ukrainy, 19 Mar. 2020, http://www.ukrstat.gov.ua/operativ/operativ2005/osv_rik/osv_u/vuz_u.html. Accessed 9 July 2020.

Dobbins, Michael. "Exploring the Governance of Polish Public Higher Education: Balancing Restored Historical Legacies with Europeanization and Market Pressures." European Journal of Higher Education, vol. 5, no. 1, 2015, pp. 18-33. DOI: $10.1080 / 21568235.2014 .969289$.

Dobbins, Michael, and Susanna Khachatryan. "Europeanization in the 'Wild East'? Analyzing Higher Education Governance Reform in Georgia and Armenia." Higher Education, vol. 69, 2015, pp. 189-207. DOI: 10.1007/s10734-014-97692.

Dobko, Taras. "Emancipating Higher Education in Ukraine from the Post-Soviet Legacy: A Problem of Trust and Academic Excellence." Universidade em Debate, vol. 1, no. 1, 2013, pp. 76-86, http://er.ucu.edu.ua/handle/1/276. Accessed 9 July 2020.

Dragneva, Rilka, and Kataryna Wolczuk. Ukraine between the EU and Russia: The Integration Challenge. Palgrave Macmillan, 2015.

Dubaseniuk, Oleksandra. "Rozvytok vyshchoi osvity: Tendentsii ta perspektyvy." Liudynotsentryzm iak osnova humanitarnoi polityky Ukrainy: Osvita, polityka, ekonomika, kul'tura, edited by Oleksandra Dubaseniuk and Olena Antonova, NAPS, 2011, pp. 135-42.

European Commission. The European Higher Education Area in 2018: Bologna Process Implementation Report. Publications Office of the European Union, 2018, https://eacea.ec.europa.eu/nationalpolicies/eurydice/sites/eurydice/files/bologna internet chapter 4 0.pdf. Accessed 9 July 2020.

European Commission et al. The European Higher Education Area in 2018: Bologna Process Implementation Report. Publications Office of the European Union, 2018. European Higher Education Area (EHEA). The Bologna Declaration of 19 June 1999. Observatory Magna Charta Universitatum, http://www.magnacharta.org/resources/files/BOLOGNA_DECLARATION.pdf. Accessed 9 July 2020. 
---. Making the Most of Our Potential: Consolidating the European Higher Education Area. The European Association for Quality Assurance in Higher Education (ENQA), 26-27 April 2012. https://enqa.eu/wpcontent/uploads/2013/03/Bucharest-Communique-20121.pdf. Accessed 9 July 2020.

---. Sorbonne Declaration 1998. EHEA, 25 May 1998, http://www.ehea.info/cid100203/sorbonne-declaration-1998.html. Accessed 9 July 2020.

---. Towards the European Higher Education Area. EHEA, 19 May 2001, http://www.ehea.info/media.ehea.info/file/2001 Prague/44/2/2001 Prague Communique English 553442.pdf. Accessed 9 July 2020.

--. The Yerevan Communique. EHEA, 14-15 May 2015. http://www.ehea.info/media.ehea.info/file/2015 Yerevan/70/7/YerevanCom muniqueFinal 613707.pdf. Accessed 9 July 2020.

Gladushyna, Olesya. "The Shifting Tides of Higher Education in Ukraine: Background, Expectations and Reality." Working Papers in Higher Education Studies, vol. 2, no. 1, 2016, pp. 95-112, https://www.wphesjournal.eu/index.php/wphes/article/view/39. Accessed 9 July 2020.

Gomilko, Olga, et al. "Hybridity in the Higher Education of Ukraine: Global Logic or Local Idiosyncrasy?" Philosophy and Cosmopology, vol. 17, 2016, pp. 177-99, http://ispcjournal.org/journals/2016-17/PC vol 17-177-199.pdf. Accessed 9 July 2020.

Harasymiw, Bohdan. "War in Ukraine: Undeclared, Unacknowledged, and Unabated." Forum for Ukrainian Studies, 29 Jan. 2015. https://ukrainianstudies.ca/2015/01/29/bohdan-harasymiw-war-ukraine-undeclaredunacknowledged-unabated/. Accessed 9 July 2020.

Hladchenko, Myroslava, et al. "Establishing Research Universities in Ukrainian Higher Education: The Incomplete Journey of a Structural Reform." Journal of Higher Education Policy and Management, vol. 38, no. 2, 2016, pp. 111-25. DOI: 10.1080/1360080X.2016.1150232.

Hurch, Liudmyla. "Pryiednannia Ukrainy do Bolons'koho Protsesu: 'Za' i 'Proty.'” Bolons'kyi Protses: Perspektyvy rozvytku vyshchoi osvity Ukrainy, edited by Volodymyr Chyrkov, Vydavnychyi dim "Personal," 2008, pp. 21-35.

International Qualifications Assessment Service (IQAS). International Education Guide for the Assessment of Education from the Former USSR and the Russian Federation. Government of Alberta, 2016. https://www.alberta.ca/documents/IQAS/russia-international-educationguide.pdf. Accessed 9 July 2020.

Johns, Michael. "Caught between Russia and NATO: The EU during and after the Ukrainian Crisis." The Return of the Cold War: Ukraine, the West and Russia, edited by J. L. Black and Michael Johns, Routledge, 2016, pp. 26-40.

Khrestin, Igor. "Constructing a Common Ukrainian Identity: An Empirical Study." Res Publica: Journal of Undergraduate Research, vol. 7, 2002, pp. 49-75, https://digitalcommons.iwu.edu/respublica/vol7/iss1/6/. Accessed 9 July 2020. 
Knight, Jane. "A Model for the Regionalization of Higher Education: The Role and Contribution of Tuning." Tuning Journal for Higher Education, vol. 1, no. 1, 2013, pp. 105-25. DOI: 10.18543/tjhe-1(1)-2013pp105-125.

Kopecky, Petr, and Cas Mudde. "The Two Sides of Euroscepticism: Party Positions on European Integration in East Central Europe." European Union Politics, vol. 3, no. 3, 2002, pp. 297-326. DOI: 10.1177/1465116502003003002.

Kostrobiy, Petro, and Yuriy Rashkevych. "Ukrainian Higher Education in 1991-2013: Successes and Failures of the Reforms." Higher Education in Ukraine: Agenda for Reforms, edited by Yevhen Nikolaiev, translated by Yana Husak, Konrad Adenauer Stiftung, 2017, pp. 15-20, https://www.kas.de/c/document library/get file?uuid=11396582-87748a81-1492-9dee7e451d2d\&groupId=252038. Accessed 9 July 2020.

Kovtun, Olena, and Sheldon Stick. "Ukraine and the Bologna Process: A Case Study of the Impact of the Bologna Process on Ukrainian State Institutions." Higher Education in Europe, vol. 34, no. 1, 2009, pp. 91-103. DOI: 10.1080/03797720902747066.

Kremen, Vasyl, and Stanislav Nikolajenko, editors. Higher Education in Ukraine. UNESCO-CEPES,

2006. https://unesdoc.unesco.org/ark:/48223/pf0000146552. Accessed 9 July 2020.

Kubicek, Paul. The History of Ukraine. Greenwood Press, 2008.

Kuraev, Alex. "Soviet Higher Education: An Alternative Construct to the Western University Paradigm." Higher Education, vol. 71, 2016, pp. 181-93. DOI: 10.1007/s10734-015-9895-5.

Kushnarenko, Valentyna, and Sonja Knutson. "Internationalization of Higher Education in Post-Soviet Ukraine." International Higher Education, vol. 75, 2014, pp. 25-27. DOI: 10.6017/ihe.2014.75.5439.

Kushnir, Iryna. "The Limits of Soft Governance in Harmonization in the European Higher Education Area." Educate: The Journal of Doctoral Research in Education, vol. 15, no. 1 2015, pp. 11-21, http://www.educatejournal.org/index.php/educate/article/view/420/331. Accessed 9 July 2020.

Kuznietsova, Viktoriia. "Bolons'kyi Protses i reformuvannia vyshchoi osvity Ukrainy." Visnyk Prydniprovs'koi derzhavnoi akademii budivnytstva ta arkhitektury, vol. 5, 2012, pp. 58-61, https://elibrary.ru/item.asp?id=23389049. Accessed 9 July 2020.

Kvit, Serhii. "Reformuvannia vyshchoi osvity v Ukraini." Osvita, 25 Oct. 2017, https://dt.ua/EDUCATION/reformuvannya-vischoyi-osviti-v-ukrayini257581.html. Accessed 9 July 2020.

Luchinskaya, Daria, and Olena Ovchynnikova. "The Bologna Process Policy Implementation in Russia and Ukraine: Similarities and Differences." European Education Research Journal, vol. 10, no. 1, 2011, pp. 21-33. DOI: 10.2304/eerj.2011.10.1.21.

Ministerstvo osvity i nauky Ukrainy. Lyst Ministerstva osvity i nauky Ukrainy "Pro zaprovadzhennia dodatka do dyploma Ievropeis'koho zrazka." No. 1/9-409, 10 June 2010, Ministerstvo osvity i nauky Ukrainy, 2010, http://old.mon.gov.ua/images/files/osvita/Evrointehraciya/1_9_409.doc. Accessed 9 July 2020. 
---. Nakaz Ministerstva osvity i nauky Ukrainy "Pro vprovadzhennia kredytnomodul'noi systemy orhanizatsii navchal'noho protsesu." No. 774, 30 Dec. 2005, Ministerstvo osvity i nauky 2005, http://old.mon.gov.ua/images/files/osvita/Evrointehraciya/mon_774.doc. Accessed 9 July 2020.

Morelli, Vincent L. Ukraine: Current Issues and U.S. Policy. CRS Report RL33460, Congressional Research Service, 3 Jan. 2017, https://fas.org/sgp/crs/row/RL33460.pdf. Accessed 9 July 2020.

Myshchyshyn, Iryna. "Natsional'na ideia ta reformuvannia osvity v Ukraini." Visnyk L'vivs'koho universytetu, vol. 23, 2008, pp. 3-9, http://dl.franko.lviv.ua/Pedagogika/periodic/visnyk/23/01 myshchyshyn.pdf Accessed 9 July 2020.

Neave, Guy. "Euro-Philiacs, Euro-Sceptics and Euro-Phobics: Higher Education Policy, Values and Institutional Research." Tertiary Education and Management, vol. 11, 2005, pp. 113-29. DOI: 10.1007/s11233-005-0688-8.

Neave, Guy, and Peter Maassen. "The Bologna Process: An Intergovernmental Policy Perspective." University Dynamics and European Integration, edited by Peter Maassen and Johan. P. Olsen, Springer, 2007, pp. 135-54.

Nikolaiev, Yevhen. "Foreword." Higher Education in Ukraine: Agenda for Reforms, edited by Yevhen Nikolaiev, translated by Yana Husak, Konrad Adenauer Stiftung, 2017, p. 3, https://www.kas.de/c/document_library/get_file?uuid=11396582-87748a81-1492-9dee7e451d2d\&groupId=252038. Accessed 9 July 2020.

---. "What Has Been Achieved by the Third Anniversary of the New Law on Higher Education?" Higher Education in Ukraine: Agenda for Reforms, edited by Yevhen Nikolaiev, translated by Yana Husak, Konrad Adenauer Stiftung, 2017, pp. 21-28. https://www.kas.de/c/document library/get file?uuid=11396582-87748a81-1492-9dee7e451d2d\&groupId=252038. Accessed 9 July 2020.

Niyozov, Sarfaroz. "Understanding Pedagogy: Cross-Cultural and Comparative Insights from Central Asia." Comparative and International Education: Issues for Teachers, edited by Kathy Bickmore et al., Canadian Scholars' P, 2017, pp. 88118.

Oleksiyenko, Anatoly. "Higher Education Reforms and Center-Periphery Dilemmas: Ukrainian Universities between Neo-Soviet and Neo-Liberal Contestations." Globalisation and Higher Education Reforms, edited by Joseph Zajda and Val Rust, Springer, 2016, pp. 133-48.

Osipian, Ararat L. "University Autonomy in Ukraine: Higher Education Corruption and the State." Communist and Post-Communist Studies, vol. 50, 2017, pp. 23343. DOI: 10.1016/j.postcomstud.2017.06.004.

Peterson, Nolan. "'Hope is Not Enough': Ukrainian University Students Prepare for War." The Daily Signal, 28 Oct. 2016, http://dailysignal.com/2016/10/28/hopeis-not-enough-ukrainian-university-students-prepare-for-war/. Accessed 9 July 2020.

Ponomar'ov, O. S., and S. A. Shpatenko. "Bolons'kyi Protses i rozvytok vyshchoi osvity v Ukraini.” Bolons'kyi Protses: Perspektyvy rozvytku vyshchoi osvity Ukrainy, edited by Volodymyr Chyrkov, Vydavnychyi dim "Personal," 2008, pp. 64-71. 
Popa, Isabella. "Displaced Universities: 18 Ukrainian Colleges Are Exiled in Their Own Country." Euromaidan Press, 25 Feb. 2017, http://euromaidanpress.com/2017/02/25/displaced-universities-how-18ukrainian-colleges-from-donbas-and-crimea-are-living-in-exile-in-their-owncountry/. Accessed 9 July 2020.

Sabzalieva, Emma. "Challenges in Contemporary Higher Education in Kyrgyzstan, Central Asia." Perspectives: Policy and Practice in Higher Education, vol. 19, no. 2, 2015, pp. 49-55. DOI: 10.1080/13603108.2015.1011727.

Scott, Peter. "Reflections on the Reforms of Higher Education in Central and Eastern Europe." The Routledge International Handbook of Higher Education, edited by Malcolm Tight et al., Routledge, 2009, pp. 269-95.

Semenets', Iu. 0. "Internatsionalizatsiia vyshchoi osvity: U poshukakh perspektyv vdoskonalennia stratehii providnykh ukrains'kykh vuziv." Naukovyi visnyk Uzhhorods'koho natsional'noho universytetu, vol. 14, no. 2, 2017, pp. 108-13, https://dspace.uzhnu.edu.ua/jspui/handle/lib/16847. Accessed 9 July 2020.

Shandruk, Svitlana, and Zhanna Shatrova. "Higher Education Reform in Ukraine during the Transition Period: On the Path to Renewal." Journal of Education and Practice, vol. 6, no. 6, 2015, pp. 135-43, https://pdfs.semanticscholar.org/9671/fc8cd0e3e25bc92ee483778a0b8bffc4 de73.pdf. Accessed 9 July 2020.

Shaw, Marta. "Flawed Implementation or Inconsistent Logics?" European Education, vol. 45, no. 1, 2013, pp. 7-24. DOI: 10.2753/EUE1056-4934450101.

Shaw, Marta, et al. "The Impact of the Bologna Process on Academic Staff in Ukraine." Higher Education Management and Policy, vol. 23, no. 3, 2011, pp. 73-91. DOI: 10.1787/hemp-23-5kg0vswcsfvf.

Shpatenko, S. A. "Vymohy tranzytyvnoho suspil'stva do systemy osvity.". Bolons'kyi Protses: Perspektyvy rozvytku vyshchoi osvity Ukrainy, edited by Volodymyr Chyrkov, Vydavnychyi dim "Personal," 2008, pp. 72-75.

Sikorskaya, Irina. "Higher Education Internationalization in Ukraine: Concerns and Hopes." International Higher Education, vol. 91, 2017, pp. 10-12. DOI: 10.6017/ihe.2017.91.10036.

Sovsun, Inna. "New Agenda for Higher Education in Ukraine: The First Stage of Changes." Higher Education in Ukraine: Agenda for Reforms, edited by Yevhen Nikolaiev, translated by Yana Husak, Konrad Adenauer Stiftung, 2017, pp. 4-14, https://www.kas.de/c/document library/get file?uuid=11396582-87748a81-1492-9dee7e451d2d\&groupId=252038. Accessed 9 July 2020.

Stensaker, Bjørn, et al. "Internationalisation of Higher Education: The Gap between National Policy-Making and Institutional Needs." Globalisation, Societies and Education, vol. 6, no. 1, 2008, pp. 1-11. DOI: 10.1080/14767720701855550.

Stepko, Mykhailo, et al. Basic Principles of the Development of Higher Education of Ukraine. Ternopil Volodymyr Hnatiuk National Pedagogical UP, 2006.

Stojic, Marko. "Between Europhobia and Europhilia: Party and Popular Attitudes towards Membership of the European Union in Serbia and Croatia." Perspectives on European Politics and Society, vol. 7, no. 3, 2006, pp. 312-35. DOI: $10.1080 / 15705850601053451$. 
Stratehichna doradcha hrupa "Osvita." Proekt: Kontseptsiia rozvytku osvity Ukrainy na period 2015-2025 Rokiv. Ternopil's'kyi natsional'nyi pedahohichnyi universytet imeni Volodymyra Hnatiuka, 2014, http://tnpu.edu.ua/EKTS/proekt koncepc.pdf. Accessed 9 July 2020.

Subtelny, Orest. Ukraine: A History. 4th ed., Toronto UP, 2009.

Ultan, Mehlika Ozlem, and Serdar Ornek. "Euroscepticism in the European Union." International Journal of Social Sciences, vol. 4, no. 2, 2015, pp. 49-57, https://www.iises.net/international-journal-of-social-sciences/publicationdetail-156. Accessed 9 July 2020.

Unynets'-Khodakivs'ka, V. P., and N. P. Matseliukh. "Vplyv Bolons'koho Protsesu na systemu navchannia ta upravlinnia u sferi vyshchoi osvity Ukrainy." Bolons'kyi Protses: Perspektyvy rozvytku vyshchoi osvity Ukrainy, edited by Volodymyr Chyrkov, Vydavnychyi dim "Personal," 2008, pp. 35-41.

Verkhovna Rada Ukrainy. Konstytutsiia Ukrainy. No. 254k/96-VR, Verkhovna Rada Ukrainy, 2020

(C)1996), http://zakon0.rada.gov.ua/laws/show/254\%D0\%BA/96-\%D0\%B2\%D1\%80. Accessed 9 July 2020.

---. Nakaz Ministerstva osvity i nauky Ukrainy "Pro zatverdzhennia planu dii shchodo zabezpechennia iakosti vyshchoi osvity Ukrainy i ii intehratsii u ievropeis'ke $i$ svitove osvitnie spivtovarystvo na period do 2010 roku." No. 612, 13 July 2007, Verkhovna Rada Ukrainy, 2020 (@2007), http://zakon.rada.gov.ua/rada/show/v0612290-07. Accessed 9 July 2020.

---. Ukaz Prezydenta Ukrainy "Pro Natsional'nu doktrynu rozvytku osvity." No. 347/2002, Verkhovna Rada Ukrainy, 2020 (C2002), https://zakon.rada.gov.ua/laws/show/347/2002. Accessed 9 July 2020.

---. Zakon Ukrainy "Pro osvitu." No. 100.96-VR, Verkhovna Rada Ukrainy, 1996. https://zakon.rada.gov.ua/laws/show/100/96-\%D0\%B2\%D1\%80\#Text. Accessed 9 July 2020.

---. Zakon Ukrainy "Pro osvitu." No. 2145-VIII, Verkhovna Rada Ukrainy, 2020 (C2017), http://zakon2.rada.gov.ua/laws/show/2145-19. Accessed 9 July 2020.

---. Zakon Ukrainy "Pro ratyfikatsiiu Konventsii pro vyznannia kvalifikatsii z vyshchoi osvity v Ievropeis'komu rehioni." No. 1273-XIV, Verkhovna Rada Ukrainy, 2020 (C1999). https://zakon3.rada.gov.ua/laws/show/1273-14. Accessed 9 July 2020.

---. Zakon Ukrainy "Pro vyshchu osvitu." No. 1556-VII, Verkhovna Rada Ukrainy, 2020 (C2014), https://zakon.rada.gov.ua/laws/main/1556-18. Accessed 9 July 2020.

---. Zakon Ukrainy "Pro vyshchu osvitu." No. 2984-III, 2014 (C2002), http://zakon2.rada.gov.ua/laws/show/2984-14. Accessed 9 July 2020.

Whiting, Kenneth R. Background Information on the Soviet Union Documentary Research Division. Aerospace Studies Institute, Air University, University of Minnesota, 1970.

Wynnyckyi, Mychailo. “New Management Challenges for Ukraine's Universities: Surviving the 2014 Reform." University Education, vol. 3, 2015, pp. 66-72. http://ir.kneu.edu.ua/handle/2010/17028. Accessed 9 July 2020. 
Yahorau, Andrei, and Sviatlana Antashkevich. Higher Education Reform in Light of Bologna Process: Opportunities, Obstacles, Context. Eastern Partnership Civil Society Forum, 2016, https://www.euneighbours.eu/en/east/stayinformed/publications/higher-education-reform-light-bologna-processopportunities. Accessed 9 July 2020.

Zeludenko, Marina, and Alla Sabitowa. "Ukraine." The Education Systems of Europe, edited by Wolfgang Hörner et al., Springer International Press, 2015, pp. 851-68.

Zmas, Aristotelis. "Global Impact of the Bologna Process: International Perspectives, Local Particularities." Compare: A Journal of Comparative and International Education, vol. 45, no. 5, 2015, pp. 727-47. DOI: 10.1080/03057925.2014.899725. 